\title{
STUDI KHASIAT EKSTRAK DAUN BAWANG PUTIH (Allium sativum) DAN DAUN KATUK (Sauropus androgynus) TERHADAP PENURUNAN KADAR KOLESTEROL DAN LEMAK ABDOMEN ITIK
}

\author{
SUMARDANI, N. L. G., BIDURA, I G. N. G., UTAMI, I. A. P., UMIYATI, A. T., \\ DAN PUTRI, B. R. T. \\ FAKULTAS PETERNAKAN UNIVERSITAS UDAYANA \\ e-mail:nlg_sumardani@yahoo.com
}

\begin{abstract}
ABSTRAK
Penelitian ini dilakukan untuk mempelajari pengaruh pemberian ekstrak daun bawang putih (Allium sativum) dan katuk (Sauropus androgynus) terhadap penurunan kadar kolesterol dan lemak abdomen itik bali jantan umur 2-8 minggu. Rancangan yang digunakan dalam penelitian ini adalah rancangan acak lengkap (RAL) dengan tiga perlakuan dan enam kali ulangan. Ketiga perlakuan tersebut adalah itik yang diberi air minum biasa sebagai kontrol (A), itik yang diberi air minum dengan 10\% ekstrak daun bawang putih (B), dan 10\% daun Katuk. Pemberian ransum dan air minum secara secara ad libitum. Hasil penelitian menunjukkan bahwa konsumsi ransum dan air minum tidak menunjukkan adanya perbedaan yang nyata $(\mathrm{P}>0,05)$ diantara perlakuan. Berat badan akhir dan pertambahan berat badan itik meningkat nyata $(\mathrm{P}<0,05)$ dengan pemberian ekstrak daun bawang putih dan daun katuk melalui air minum. Sebaliknya, kadar kolesterol dalam serum darah dan jumlah lemak abdomen itik menurun secara nyata $(\mathrm{P}<0,05)$. Hasil penelitian ini dapat disimpulkan bahwa pemberian $10 \%$ ekstrak daun bawang putih (Allium sativum) dan katuk (Sauropus androgynus) dapat meningkatkan penampilan dan menurunkan kandungan serum kolesterol darah dan jumlah lemak abdomen itik bali umur 2-8 minggu.
\end{abstract}

Kata kunci: ekstrak daun bawang putih, katuk, lemak abdomen, kolesterol, itik

\section{THE STUDY OF GARLIC (ALLIUM SATIVUM) AND KATUK LEAF MEAL EXTRACT (SAUROPUS ANDROGYNUS) ON DRINKING WATER FOR DECREASING PLASMA CHOLESTEROL AND ABDOMINAL FAT OF BALI DUCKLING}

\begin{abstract}
This experiment was carried out to study the effect of garlic (Allium sativum) and katukleaf meal extract (Sauropus androgynus) on drinking water for decreasing of cholesterol content of blood serum and abdominalfat of bali duckling up to eight weeks of age. A completely randomized design (CRD) with three treatments and six replicates using four birds with homogenuous body weight in each replicates. The treatments were birds offered drinking water without Garlic or katuk leaf meal extract as control (A), drinking water with Garlic (B), and katuk leaf meal extract (C), respectively. All diets were in mash form. Feed and water were offered ad libitum. The result showed that birds offered with 10\% garlic (Allium sativum) and katuk leaf meal extract(Sauropus androgynus) on their drinking water did not effect significantly different $(\mathrm{P}>0,05)$ on feed and water consumption but increased significantly different $(\mathrm{P}<\mathrm{O}, \mathrm{O} 5)$ on final body weight and body weight gains (LWG) than control (A). In contrast, cholesterol content of blood serum and abdominal-fat of birds in treatment B and C decreased significantly different $(\mathrm{P}<0,05)$ than control. It can be concluded that birds offered with $10 \%$ garlic (Allium sativum) and katuk leaf meal extract (Sauropus androgynus) on drinking water increased performance and decreased cholesterol content of blood serum and abdominal-fat of Bali duckling (two up to eight weeks of age).
\end{abstract}

Key words: garlic leaf meal extract, katuk, abdominal fat, cholesterol, duck

\section{PENDAHULUAN}

Pengetahuan tradisional tentang pemanfaatan tumbuhan sangat penting artinya, karena akan menambah keanekaragaman sumberdaya nabati dan merupakan dasar botani ekonomi maupun botani terapan lainnya (Soekarman dan Riswan, 1992). Menurut Santoso (l993), kandungan bahan alami tumbuhan berkhasiat adalah bahan organik sekunder yang dihasilkan melalui reaksi sekunder dari bahan organik primer (karbohi- 
drat, lemak, dan protein).

Pertumbuhan yang cepat pada itik yang dipelihara secara intensif sering diikuti dengan perlemakan yang tinggi. Tingginya kandungan lemak dalam tubuh, khususnya kandungan lemak jenuh, akan diikuti dengan tingginya kandungan kolesterol dan hal tersebut akan menjadi masalah bagi konsumen yang menginginkan daging yang berkualitas baik. Oleh karena itu, perlu dilakukan usaha-usaha untuk menurunkan lemak dan kolesterol pada produk ternak unggas (Santoso, 2000).

Alternatif bahan pakan yang menarik diamati adalah pemanfaatan limbah pertanian dalam ransum ternak, karena bahan pakan ini ketersediaannya cukup banyak dan tidak bersaing dengan manusia. Daun bawang putih (Allium sativum) misalnya, ketersediaannya cukup banyak khususnya di daerah pertanian seperti Kecamatan Penebel, Kabupaten Tabanan, dan Kecamatan Kintamani, Kabupaten Bangli.

Bawang putih (Allium sativum) selain dikenal sebagai tanaman obat tradisional dan bumbu masak yang sampai kini masih dipergunakan di seluruh dunia, ternyata mempunyai khasiat medis. Menurut Karyadi (l997), bawang putih mengandung senyawa fitokimia, yaitu suatu zat kimia alami yang terdapat di dalam tumbuhan atau tanaman yang mempunyai fungsi faali luar biasa. Jenis fitokimia yang dikandung oleh tanaman bawang putih adalah allyl sulfide yang mempunyai fungsi sebagai antikanker, antimikroba, antioksidasi, antitrombotik, antiinflamasi, merangsang sistem imun, mengatur tekanan darah, dan menurunkan kandungan kolesterol darah. Hal lain yang dapat dimanfaatkan dari khasiat bawang putih adalah adanya kemampuan sebagai antimikroba dan antioksidasi, sehingga keberadaannya dalam ransum akan dapat meningkatkan lama penyimpanan. Menurut Augusti (1977), pengaruh bawang putih terhadap lipida darah adalah disebabkan karena adanya senyawa yang mengandung sulfur pada bawang putih seperti allicin. Rantai samping dari allil tak jenuh ini mudah direduksi menjadi rantai prophyl tak jenuh dan proses ini mengakibatkan penurunan NAD dan NADP dalam tubuh. Selain itu Allicin juga dianggap mampu berikatan dengan gugus-SH yang merupakan bagian fungsionil dari koenzim-A dalam proses pembentukan kolesterol. Beberapa penelitian pada manusia dan hewan membuktikan bahwa zat-zat kombinasi fitokimia ini di dalam tubuh manusia atau ternak memiliki fungsi tertentu yang berguna bagi kesehatan. Kombinasi tersebut antara lain menghasilkan enzim-enzim penangkal racun (detoksifikasi), menghambat sintesis kolesterol, meningkatkan metabolisme hormon, antibakteri, antioksidan, mengatur gula darah, dan antikanker (Karyadi, l997).

Demikian juga halnya dengan daun katuk (Sauropus androgynus) merupakan tanaman obat-obatan tradisionil yang mempunyai zat gizi tinggi, sebagai antibakteri, dan mengandung beta karoten sebagai zat aktif warna karkas. Senyawa fitokimia yang terkandung didalamnya adalah: saponin, flavonoid, dan tanin (Santoso, 2000). Menurut Karyadi (1997), isoflavonoid yang menyerupai estrogen ternyata mampu meperlambat berkurangnya massa tulang (osteomalasia), menurunkan kadar kolesterol darah dan meningkatkan kadar HDL, sedangkan saponin terbukti berkhasiat sebagai antikanker, antimikroba, dan menurunkan kadar kolesterol darah.

Hasil penelitian pendahuluan menunjukkan bahwa penggunaan tepung daun bawang putih dalam ransum, nyata dapat meningkatkan efisiensi penggunaan ransum dan pertumbuhan itik (Bidura dan Suwidjayana, 1998). Peneliti menduga, meningkatnya efisiensi penggunaan ransum dan pertumbuhan itik, kemungkinan disebabkan karena adanya khasiat fitokimia pada jerami bawang putih tersebut. Dilaporkan juga oleh Santoso (1999) bahwa pemberian 3\% tepung daun katuk dalam ransum ayam nyata menurunkan akumulasi lemak, menurunkan bau amis daging, serta mampu menekan jumlah Salmonella sp dan E. choli daging.

Belum banyak informasi mengenai pengaruh penggunaan ekstrak daun bawang putih dan daun katuk melalui air minum yang diberikan terhadap penampilan dan penurunan kadar kolesterol tubuh itik, menjadikan penelitian ini perlu dilaksanakan.

\section{MATERI DAN METODE}

\section{Tempat Penelitian}

Penelitian dilaksanakan di kandang milik petani peternak di Desa Dajan Peken, Kaupaten Tabanan, Bali dan Laboratorium Teknologi Hasil Ternak, Fakultas Peternakan, Unud.

\section{Kandang dan Itik}

Kandang yang digunakan adalah kandang "battery colony" yang terbuat dari kawat burung dan bilah bambu. Ukuran tiap petak kandang, yaitu panjang 100 $\mathrm{cm}$, lebar $60 \mathrm{~cm}$, dan tinggi $40 \mathrm{~cm}$. Tiap petak kandang sudah dilengkapi dengan tempat pakan dan air minum.

Itik yang digunakan adalah itik bali jantan umur dua minggu dengan berat badan homogen. Itik diperoleh dari petani peternak itik bali di daerah Tabanan, Bali.

\section{Ransum dan air Minum}

Ransum yang diberikan adalah ransum konsentrat berbentuk tepung yang disusun menggunakan bahan, seperti jagung, dedak padi, bungkil kelapa, tepung ikan, minyak kelapa, dan mineral. Ransum disusun dengan kandungan energi termetabolis $2900 \mathrm{kkal} / \mathrm{kg}$ dan protein kasar $18 \%$. Air minum bersumber dari PAM setempat. 
Tabel 1. Komposisi Pakan dalam Ransum Itik Bali Jantan Umur 2-8 Minggu

\begin{tabular}{|c|c|c|c|}
\hline \multirow{2}{*}{ Komposisi Pakan (\%) } & \multicolumn{3}{|c|}{ Perlakuan ${ }^{2)}$} \\
\hline & $\mathrm{A}$ & $\mathrm{B}$ & $\mathrm{C}$ \\
\hline Jagung kuning & 51,95 & 51,95 & 51,95 \\
\hline Bungkil kelapa & 12,45 & 12,45 & 12,45 \\
\hline Dedak padi & 10,00 & 10,00 & 10,00 \\
\hline Kacang kedelai & 13,60 & 13,60 & 13,60 \\
\hline Pollard & 2,60 & 2,60 & 2,60 \\
\hline Tepung ikan & 8,00 & 8,00 & 8,00 \\
\hline Minyak kelapa & 0,50 & 0,50 & 0,50 \\
\hline Garam dapur & 0,40 & 0,40 & 0,40 \\
\hline Mineral mix & 0,50 & 0,50 & 0,50 \\
\hline Ekstraks daun bawang putih ${ }^{1)}$ & & - & + \\
\hline Ekstrak daun katuk ${ }^{1)}$ & & + & - \\
\hline Total & & 100 & 100 \\
\hline
\end{tabular}

Keterangan:

1) Ekstrak duan bawang putih dan daun katuk diberikan melalui air minum, yaitu sebanyak $10 \%$ dari total air minum yang diberikan.

2) Ransum untuk itik Bali jantan umur 2-8 minggu dengan kandungan protein $18 \%$ dan energi termetabolis $2900 \mathrm{kkal} / \mathrm{kg}$ ransum

Tabel 2. Komposisi Zat Makanan dalam Ransum Itik Bali Jantan Umur 2-8 Minggu $^{1)}$

\begin{tabular}{|c|c|c|c|c|c|}
\hline \multirow{2}{*}{\multicolumn{2}{|c|}{ Zat Makanan }} & \multicolumn{3}{|c|}{ Perlakuan } & \multirow{2}{*}{ Standar } \\
\hline & & \multirow{2}{*}{$\frac{A}{2902}$} & \multirow{2}{*}{$\begin{array}{c}\text { B } \\
2900\end{array}$} & \multirow{2}{*}{$\frac{C}{2900}$} & \\
\hline Energi metaboli & kal/kg) & & & & 2900 \\
\hline Protein kasar & $(\%)$ & 18 & 18 & 18 & 18 \\
\hline Lemak kasar & (\%) & 6,76 & 6,76 & 6,76 & $5-8^{21}$ \\
\hline Serat Kasar & $(\%)$ & 4,85 & 4,85 & 4,85 & $3-8^{21}$ \\
\hline Kalsium & (\%) & 1,08 & 1,08 & 1,08 & 0,60 \\
\hline Fosfor tersedia & $(\%)$ & 0,63 & 0,63 & 0,63 & 0,35 \\
\hline Arginin & (\%) & 1,52 & 1,52 & 1,52 & 1,00 \\
\hline Met + Sistin & (\%) & 0,79 & 0,79 & 0,79 & 0,60 \\
\hline Lysin & (\%) & 1,31 & 1,31 & 1,31 & 0,80 \\
\hline
\end{tabular}

Keterangan :

1) Berdasarkan perhitungan menurut tabel komposisi Scott et al. (1982)

2) Standar NRC (1984)

\section{Ekstrak Daun Bawang Putih dan Daun Katuk}

Daun daun bawang putih yang dipergunakan adalah daun bawang putih (Allium sativum L.) dan daun katuk (Sauropus androgynus) lokal setempat yang sudah tua (warna hijau sampai kuning). Kedua daun tersebut kemudian dihancurkan di dalam air minum biasa untuk mendapatkan ekstraknya dengan perbandingan $300 \mathrm{~g}$ dalam satu liter air minum.

\section{Rancangan Penelitian}

Rancangan yang dipergunakan dalam penelitian ini adalah rancangan acak lengkap (RAL) dengan tiga perlakuan dan enam ulangan. Tiap ulangan mempergunakan empat ekor itik bali jantan dewasa (umur dua minggu) dengan berat badan homogen. Ketiga perlakuan tersebut adalah:

- itik yang diberi air minum tanpa ekstrak daun bawang putih atau katuk sebagai kontrol (A).

- itik yang diberi 10\% ekstrak daun bawang putih me- lalui air minum (B)

- itik yang diberi 10\% ekstrak daun katuk melalui air minum (C)

\section{Pemberian Ransum dan Air Minum}

Ransum dan air minum diberikan ad libitum. Pemberian ransum dilakukan dengan cara mengisi 3/4 bagian dari tempat ransum untuk menghindari tercecernya ransum pada saat itik makan. Penggantian air minum dilakukan setiap hari untuk menghindari timbulnya penyakit.

\section{Pemotongan Itik}

Pengambilan itik yang akan dipotong dilakukan pada akhir penelitian, yaitu satu ekor pada masing-masing unit percobaan. Itik yang dipotong adalah itik yang mempunyai bobot badan mendekati rata-rata bobot badan pada masing-masing unit percobaan. Sebelum pemotongan dimulai, itik dipuasakan selama 12 jam dan hanya diberikan air minum saja. Pemotongan dilakukan menurut USDA (1977), yaitu itik dipotong pada bagian Vena jugularis yang terletak diantara tulang kepala dengan ruas tulang leher pertama.

\section{Variabel yang diamati}

Variabel yang diamati meliputi selama penelitian antara lain:

- Konsumsi ransum dan air minum: jumlah ransum dan air minum yang diberikan dikurangi dengan sisa.

- Berat badan akhir, merupakan rataan berat badan itik pada masing-masing unit percobaan pada akhir penelitian.

- Kadar kolesterol darah: pengamatan kadar kolesterol darah dilakukan sekali, yaitu pada minggu terakhir penelitian dengan menggunakan darah yang diambil pada bagian sayap. Analisis kolesterol menggunakan metode Lieberman-Burchad dari Plummer (1977). Larutan sterol dalam kloroform dieraksikan dengan asam asetat anhidrat asam sulfat pekat. Dalam uji nanti dihasilkan warna dari hijau kebiruan sampai warna hijau, tergantung kadar kolesterol sampel. Larutan yang dihasilkan tertera pada spektrofotometer untuk mendapatkan densitas optik (DO). Hasil tersebut kemudian dibandingkan dengan DO dari larutan standar, sehingga dapat dihitung besarnya kadar kolesterol sampel

- Lemak abdomen, yaitu lemak yang ada di dalam rongga perut termasuk lemak bantalan (pad-fat)

\section{Analisis Statistik}

Data dianalisis dengan sidik ragam, apabila diantara perlakuan menunjukkan adanya perbedaan yang nyata $(\mathrm{P}<0,05)$ dilanjutkan dengan uji jarak berganda dari Duncan (Steel dan Torrie, l989). 


\section{HASIL DAN PEMBAHASAN}

Hasil penelitian menunjukkan bahwa jumlah ransum yang dikonsumsi oleh itik yang diberi ekstrak daun bawang putih (B) dan ekstrak daun katuk (C) melalui air minum masing-masing: 7,94\% dan 6,36\% lebih tinggi daripada kontrol dan secara statistik tidak berbeda nyata $(\mathrm{P}>0,05)$ dan pemberian ekstrak daun bawang putih (B) dan daun katuk (C) ternyata tidak berpengaruh nyata $(\mathrm{P}>0,05)$ terhadap konsumsi air minum (Tabel 3). Ini menunjukkan bahwa kandungan senyawa fitokimia pada daun bawang putih dan daun katuk tidak mampu meningkatkan konsumsi ransum. Secara teoritis, konsumsi ransum sangat dipengaruhi oleh kandungan energi dalam ransum. Seperti dilaporkan oleh Wahyu (1978), bahwa kandungan energi metabolis dalam ransum merupakan faktor utama yang mempengaruhi tingkat konsumsi oleh ternak unggas. Namun demikian, sudah tampak ada kecendrungan konsumsi ransum meningkat dengan adanya pemberian ekstrak daun bawang putih dan katuk melalui air minum. Faktor pertumbuhan akan ikut mempengaruhi jumlah ransum yang dikonsumsi. Hal ini logis, karena meningkatnya pertumbuhan akan diikuti dengan meningkatnya kebutuhan akan zat makanan, khususnya energi. Meningkatnya pertumbuhan itik, secara kumulatif akan meningkatnya kebutuhan akan zat makanan dan sebagai konsekuensi logis, itik akan meningkatkan konsumsi ransum maupun zat makanan lainnya.

Tabel 3. Pengaruh Pemberian Ekstrak Daun Bawang Putih dan Daun Katuk melalui Air Minum terhadap Penampilan Itik Bali Jantan Umur 2-8 Minggu

\begin{tabular}{lrrrr}
\hline \multirow{2}{*}{ Variabel } & \multicolumn{4}{c}{ Perlakuan $^{1)}$} \\
\cline { 2 - 5 } & $\mathrm{A}$ & $\mathrm{B}$ & $\mathrm{C}$ & \\
\hline $\begin{array}{l}\text { Konsumsi ransum } \\
\text { (g/ekor/6 minggu) }\end{array}$ & $5386,8 \mathrm{a}^{3)}$ & $5814,7 \mathrm{a}$ & $5729,5 \mathrm{a}$ & 83,89 \\
$\begin{array}{l}\text { Konsumsi air minum } \\
\text { (I/ekor/6 minggu) }\end{array}$ & $15,925 \mathrm{a}$ & $17,046 \mathrm{a}$ & $16,961 \mathrm{a}$ & 1,835 \\
$\begin{array}{l}\text { Berat badan akhir } \\
\text { (g/ekor) }\end{array}$ & $1106,52 \mathrm{~b}$ & $1278,05 \mathrm{a}$ & $1246,73 \mathrm{a}$ & 16,802 \\
$\begin{array}{l}\text { Pertamb berat } \\
\text { badan (g/ekor/6mg) }\end{array}$ & $831,74 \mathrm{~b}$ & $1002,36 \mathrm{a}$ & $970,92 \mathrm{a}$ & 31,083 \\
$\begin{array}{l}\text { Abdominal-fat (\% } \\
\text { berat hidup) }\end{array}$ & $1,98 \mathrm{a}$ & $1,72 \mathrm{~b}$ & $1,63 \mathrm{~b}$ & 0,029 \\
$\begin{array}{l}\text { Kolesterol plasma } \\
\text { (mg/dl) }\end{array}$ & $185,07 \mathrm{a}$ & $169,41 \mathrm{~b}$ & $167,35 \mathrm{~b}$ & 4,072 \\
\hline
\end{tabular}

Keterangan:

1) Itik yang diberi air minum tanpa ekstrak daun bawang putih atau katuk sebagai kontrol (A), itik yang diberi air minum yang mengandung $10 \%$ ekstrak daun bawang putih (B), dan $10 \%$ ekstraks daun katuk (C).

2) Standard Error of The Treatment Means

3) Nilai dengan huruf yang sama pada baris yang sama menunjukkan tidak berbeda nyata $(P>0,05)$

Pemberian ekstrak daun bawang putih (B) dan daun katuk (C) melalui air minum secara nyata $(\mathrm{P}<0,05)$ dapat meningkatkan berat badan akhir itik masing-masing: $15,50 \%$ dan $12,67 \%$ lebih tinggi daripada kontrol
(Tabel 3). Hal ini disebabkan karena senyawa fitokimia pada daun bawang putih dan katuk dapat meningkatkan efisiensi penggunaan zat makanan, khususnya protein. Komponen bersulfur pada bawang putih akan meningkatkan ketersediaan asam amino yang mengandung sulfur seperti metionin dalam tubuh ayam. Menurut Seaton et al. (1978), meningkatnya konsentrasi asam amino metionin dalam tubuh akan dapat meningkatkan pertumbuhan ayam. Kombinasi senyawa fitokimia di dalam tubuh dapat menghasilkan enzimenzim penangkal racun, merangsang sistem kekebalan, mencegah penggumpalan keping-keping darah (trombosit), meningkatkan metabolisme hormon, dan pengikatan zat karsinogen dalam usus, efek antibakteri, dan antioksidan (Karyadi, l997) yang semuanya akan berdampak pada peningkatan pertumbuhan ayam. Menurut Sugahara dan Kubo (1992), konsumsi protein dan asam amino lysin yang tinggi akan dapat meningkatkan retensi energi sebagai protein dan menurunkan retensi energi sebagai lemak dalam tubuh. Pendapat ini didukung oleh Sibbald dan Wolynetz (1986), bahwa retensi energi sebagai protein meningkat, sedangkan retensi energi sebagai lemak tubuh menurun dengan semakin meningkatnya konsentrasi asam amino lysin dalam tubuh sebagai akibat meningkatnya konsumsi protein atau asam amino lysin.

Trisnadewi dan Candraasih (2008) melaporkan bahwa penggantian 100\% jagung kuning dalam ransum dengan campuran limbah roti dan tepung jerami bawang putih (LRBP) nyata dapat meningkatkan penampilan dan menurunkan lemak abdomen serta kadar kolesterol plasma darah itik Bali jantan umur 2-8 minggu. Dilaporkan juga oleh Witariadi et al. (2007) bahwa penggunaan 3\% dan 6\% tepung jerami bawang putih (Allium sativum) dalam ransum, secara nyata dapat meningkatkan pertambahan berat badan, konsumsi ransum, efisiensi penggunaan ransum, berat karkas, dan persentase daging karkas dibandingkan dengan kontrol. Sebaliknya, menurunkan jumlah pad-fat, $a b-$ dominal-fat, dan kadar kolesterol dalam plasma darah broiler umur 2-6 minggu.

Hasil penelitian ini menunjukkan bahwa pemberian ekstrak daun bawang putih dan daun katuk melalui air minum secara nyata $(\mathrm{P}<0,05)$ dapat menekan akumulasi lemak dan kadar kolesterol pada plasma darah itik bali (Tabel 3). Penurunan ini sebagai akibat dari peningkatan konsumsi protein dan asam amino lysin. Seperti dilaporkan oleh Al-Batshan dan Hussein (1999), meningkatnya konsumsi protein secara nyata akan meningkatkan berat karkas, persentase karkas, persentase daging dada ("breast meat"), dan nyata menurunkan lemak abdomen ("abdominal fat"). Penurunan akumulasi lemak tersebut dapat juga disebabkan karena saponin pada daun katuk dan daun bawang putih, dapat mengi- 
kat garam empedu endogenus (endogenus bile cholesterol). Saponin dapat menurunkan kadar lipida dan kolesterol darah dengan jalan menghambat penyerapan koletserol endogenus diatas. Disamping itu, saponin juga dapat menghambat aktivitas enzim pankreas dan produk metabolitnya, serta dapat membentuk senyawa kompleks yang tidak larut dengan Zn (Ferket dan Middelton, 1999). Dilaporkan juga oleh Wibowo (1990) bahwa kerja senyawa fitokimia (scordinin) pada kedua ekstrak daun tersebut ternyata sama dengan enzim $o k-$ sido-reduktase.

Scordinin berfungsi sebagai enzim pendorong pertumbuhan yang efektif pada ternak. Hal ini telah dibuktikan pada tikus dan kelinci, dimana scordinin mampu menekan kandungan lipida dan koletserol dalam darah kelinci jantan. Garam empedu sangat dibutuhkan sekali untuk mengemulsikan lemak yang akan dimakan, sehingga bisa dicerna oleh enzim lipase (Siregar et al., 1982). Hasil penelitian ini diperkuat oleh Santoso (2000), bahwa pemberian tepung daun katuk tua sebanyak 3\% dalam ransum nyata menurunkan akumulasi lemak dan meningkatkan efisiensi penggunaan ransum tanpa menurunkan berat badan ayam. Demikian juga halnya pada pemberian ekstrak daun katuk sebanyak 4,5 g/liter air minum, nyata menurunkan akumulasi lemak dalam tubuh, meningkatkan efisiensi penggunaan ransum, menurunkan jumlah Salmonella sp., dan $E$. coli pada daging ayam.

Dari hasil penelitian ini dapat disimpulkan bahwa pemberian 10\% ekstrak daun bawang putih (Allium sativum) dan katuk (Sauropus androgynus) nyata dapat meningkatkan penampilan dan menurunkan kandungan serum kolesterol darah dan jumlah lemak abdomen itik bali umur 2-8 minggu.

\section{UCAPAN TERIMAKASIH}

Pada kesempatan ini penulis mengucapkan banyak terimakasih kepada Bapak Rektor dan Ketua Lemlit Unud atas dana yang diberikan melalui dana DIK Unud, sehingga penelitian sampai penulisan paper ilmiah ini dapat terlaksana. Ucapan yang sama disampaikan juga kepada teman-teman sejawat atas kerjasamanya dalam penelitian.

\section{DAFTAR PUSTAKA}

Al-Batshan, H.A., dan Hussein, E.O.S. 1999. Performance and Carcass Composition of Broiler Under Heat Stress: 1. The Effect of Dietary Energy and Protein. Asian-Aus. J. Animal Sci. 12(6): 914-922

Augusti, K.T. 1977. Hypocolesterolemic Effect of Garlic (Allium sativum). 211-214. Linn. Indian. J. Axp. Biol. 15: 489-490
Bidura, I.G.N.G. dan I. N. Suwidjayana. 1998. Khasiat Tepung Jerami Bawang Putih (Allium sativum) Menurunkan Kandungan Lemak dan kolesterol Karkas Itik. Laporan Penelitian BBI, Dirjen Dikti, Fapet. Unud. Denpasar

Ferket P.R. And Middelton, T. 1999. Antinutrien Feed-stuff. Poultry International. March. 1999. 38(3): 46-55

Karyadi, E. l997. Khasiat Fitokimia Bagi Kesehatan. Harian Kompas, Minggu, 20 Juli 1997. Hal: 15, Kol: 1-7, PT. Gramedia, Jakarta.

National Research Council (NRC). 1994. Nutrient Requirements of Poultry. $8^{\text {th }}$ Revised Ed. Natural Academy Press. Washington D. C.

Plummer, D. T. 1977. An Introduction to Practical Biochemistry. McGraw-Hill Book Co. Ltd. New Delhi.

Santoso. 1993. Fisiologi Tumbuhan. Fakultas Biologi. Universitas Gadjah Mada, Yogyakarta.

Santoso, U. 2000. Mengenal Daun Katuk Sebagai Feed Additive pada Broiler. Poultry Indonesia, Juni/Nomor 242: $59-60$

Scott, M.L., M.C. Nesheim and R.J. Young. 1982. Nutrition of the Chicken. 2nd Ed. M.L. Scott and Assoc. Ithaca.

Seaton K. W., O. P. Thomas, R. M. Gous, and E. H. Bossard .1978. The Effect of Diet on Liver Glycon and Body Composition in the Chick. Poultry Sci. 57: 692-697.

Sibbald, I. R., and M. S. Wolynetz. 1986. Effect of Dietary Lysine and Feed Intake on Energy Utilization and Tissue Synthesis by Broiler Chicks. Poultry Sci. 65: 98-105.

Siregar, A. P., Cumming, K. B., and Farrel, D. J. 1982. The Nutrition of Meat Type Duck II. The Effect of Fibrin on Biological Performance and Carcass Characteristic. Aust. J. Agric. Res.: 3:877-886.

Soekarman dan S. Riswan. 1992. Status Pengetahuan Etnobotani di Indonesia. Perpustakaan Nasional RI dan Litbang Botani, Puslitbang LIPI, Bogor, dalam Prosiding Seminar dan Lokakarya Nasional Etnobotani, Cisarua, Bogor, 19-20 Februari LIPI dan Lembaga Perpustakaan Nasional RI. Hal: 1-7

Steel, R.G.D. and Torrie, J.H. 1989. Principles and Procedure of Statistics. McGraw Hill Book Co. Inc., New York.

Trisnadewi, A. A. A. dan Candraasih, N.N.K. 2008. Penggantian penggunaan jagung kuning dengan campuran limbah roti dan tepung jerami bawang putih terhadap penampilan, perlemakan, dan kadar kolesterol daging itik. Laporan Penelitian Berbagai Bidang Ilmu, Dirjen Dikti, Depdiknas, Jakarta

USDA. 1977. Poultry Grading Manual. U. S. Government Printing Office. Washington D. C. 20402.

Wahyu, J. 1978. Cara Pemberian dan Penyusunan Ransum Unggas. Cetakan ke-4. Fakultas Peternakan Institut Pertanian Bogor.

Wibowo, S. 1990. Budidaya Bawang. Bawang Putih, Bawang Merah, Bawang Bombay. Cetakan III. Penebar Swadaya, Anggota IKAPI, Jakarta.

Witariadi, N. M., Wirayasa, I. N., dan Bidura, I G.N.G,. 2007. Studi khasiat tepung jerami bawang putih (Allium sativum) tingkatkan penampilan dan turunkan kadar kolesterol tubuh ayam. Laporan Penelitian Dosen Muda, Dirjen Dikti, Depdiknas, Jakarta 